\title{
PERBANDINGAN VOLUME KEBUTUHAN MATERIAL KUDA-KUDA RANGKA ATAP BAJA TIPE PRATT, HOWE, COMPOUND FAN
}

\author{
Irika Widiasanti, Adhi Purnomo, Arif Budiman
}

\begin{abstract}
Abstrak
Penelitian ini bertujuan untuk mengetahui perbandingan kebutuhan material baja pada kuda-kuda bentuk Pratt truss, Howe Truss, dan Compound Fan Truss sehingga dapat diketahui jumlah penggunaan kebutuhan material baja terkecil. Penelitian ini akan membandingkan tiga tipe kuda-kuda pada panjang bentangan $24 \mathrm{~m}$.

Perhitungan gaya batang pada kuda-kuda menggunakan program SAP 2000 yang didasarkan oleh beban mati, beban hidup, dan beban angin yang bekerja pada struktur kuda-kuda sesuai dengan SNI-03-1727-1989 tentang Tata Cara Pembebanan Untuk Rumah dan Gedung. Data perhitungan gaya batang didapat, selanjutnya ditentukan jenis profil baja yang sesuai dengan besarnya gaya dan jenis batang yang berkerja yaitu batang tarik dan tekan. Perhitungan dimensi profil pada batang kuda-kuda dilakukan sesuai dengan SNI 03-1729-2002 tentang Tata Cara Perencanaan Struktur Baja Untuk Bangunan Gedung.

Berat parameter profil di setiap batang kemudian dikalikan dengan panjangnya sehingga diketahui volume material baja yang diperlukan dalam satuan kilogram $(\mathrm{kg})$. Volume seluruh batang dijumlahkan dan kemudian dibandingkan dengan bentuk kuda-kuda yang lainnya.Perbandingan dilakukan untuk mendapatkan bentuk kuda-kuda yang paling sedikit menggunakan bahan material baja.

Kesimpulan penelitian ini adalah pada bentang $24 \mathrm{~m}$ bentuk kuda-kuda Compound Fan Truss memiliki jumlah kebutuhan material baja terkecil yaitu sebesar 1220,51 kg. Kuda-kuda Howe Truss memiliki jumlah kebutuhan pemakaian material baja dengan nilai sebesar 1870,12 kg, sedangkan kuda-kuda Bentuk Pratt Truss memiliki jumlah kebutuhan material baja terbesar pada bentang ini yaitu 2112,37 kg.
\end{abstract}

Kata kunci : kuda-kuda baja, kebutuhan material

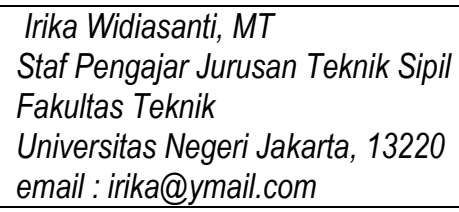

Adhi Purnomo, MT Staf Pengajar Jurusan Teknik Sipil Fakultas Teknik

Universitas Negeri Jakarta, 13220 email : adhi_purnomo@ymail.com
Arif Budiman

Alumni Jurusan Teknik Sipil

Fakultas Teknik

Universitas Negeri Jakarta, 13220 


\section{PENDAHULUAN}

Penggunaan kuda-kuda rangka atap baja di dalam dunia konstruksi sudah menjadi populer pada saat ini. Kuda-kuda rangka atap baja sering digunakan karena sifat dari bahan baja yang menguntungkan dalam dunia konstruksi. Keunggulan bahan baja sebagai bahan material konstruksi antara lain adalah berkekuatan tinggi, keseragaman dimensi penampang,daktilitas yang tinggi, modulus elastisitas sama untuk tarik dan tekan, dapat digunakan dalam bentangan yang relatif besar, cepat dalam pelaksanaan, dan mempunyai daya tahan yang cukup kuat untuk konstruksi terlindung (http://repository.usu.ac.id , 2011).

Akibat penggunaan bahan baja yang sangat menguntungkan dan proses pengolahan sumber daya dari bahan baja tersebut terbilang sangat sulit, mengakibatkan harga material baja semakin mahal. Penggunaan bahan baja harus direncanakan dengan baik dan benar supaya tidak terlalu banyak mengeluarkan biaya pada saat perangkaian kuda-kuda. Oleh karena itu, faktor yang sangat menarik untuk diperhatikan lebih lanjut adalah jumlah pemakaian material baja yang diperlukan dalam pembuatan struktur kuda-kuda baja haruslah ekonomis dalam penggunaan bahan dan aman. Semakin kecil kebutuhan material suatu kuda-kuda baja, maka akan semakin ekonomis biaya yang dikeluarkan dalam pembuatannya.

Banyaknya bentuk rangka kuda-kuda yang ada di dunia konstruksi, membuat seorang perencana haruslah dapat memilih bentuk rangka kuda-kuda yang paling ekonomis dalam pemakaian bahan dan pelaksanaan di lapangan. Pemilihan bentuk kuda-kuda haruslah dilakukan secara cermat dan tepat dimana rangka kuda-kuda yang dipilih haruslah sesuai dengan bahan yang akan digunakan yaitu baja.

Kuda-kuda rangka atap baja tipe Pratt Truss $(6-30 \mathrm{~m})$, Howe Truss (6-24 m), dan Compound Fan Truss (24-27 m) merupakan bentuk kuda-kuda yang bisa dipergunakan pada bentangan yang besar dengan material baja. Ketiga bentuk kuda-kuda tersebut sangat cocok digunakan pada bentangan yang lebih panjang (diatas $12 \mathrm{~m}$ ). Ketiga bentuk kuda-kuda rangka atap baja ini dapat dipergunakan sesuai dengan maksud perencanaan struktur atap pada bentangan $24 \mathrm{~m}$. Selain itu ketiga kuda-kuda tersebut dapat dipakai/dipilih pada bangunan yang sedang berkembang dewasa ini seperti bangunan industri (pabrik dan gudang), hanggar pesawat, gelanggang olahraga, dan bangunan dengan bentangan yang besar lainnya.

Baja adalah nukam logam murni dengan unsur paduan Ferro (Besi) dan sedikit zat $\operatorname{arang}(\mathrm{C})$, Silisium (Si), Mangan (Mn), Phospor $(\mathrm{P})$, Belerang $(\mathrm{S})$, dan lain-lain. Baja mempunyai keteguhan yang keras dan ke-liatanya, titik lelehnya $1460^{\circ} \mathrm{C}-1520^{\circ} \mathrm{C}$, berat jenis 7,85 dan angka pemuaiannya sampai 0,000012 tiap $1{ }^{\circ} \mathrm{C}$ (Daryanto 1998). 
Sifat-sifat mekanis baja struktural untuk maksud perencanaan ditetapkan sebagai berikut (SNI 03-1729-2002).

$\begin{array}{ll}\text { Modulus elastisitas : } E & =200.000 \mathrm{MPa} \\ \text { Modulus geser }: G & =80.000 \mathrm{MPa} \\ \text { Nisbah poisson }: \mu & =0,3 \\ \text { Koefisien pemuaian }: \alpha & =12 \times 10^{-6} /{ }^{\circ} \mathrm{C}\end{array}$

Tabel.1. Sifat mekanis baja struktural

\begin{tabular}{|c|c|c|c|}
\hline Jenis Baja & $\begin{array}{c}\text { Tegangan putus } \\
\text { minimum, } f_{\mathrm{u}} \\
(\mathrm{MPa})\end{array}$ & $\begin{array}{c}\text { Tegangan leleh } \\
\text { minimum, } f_{y} \\
(\mathrm{MPa})\end{array}$ & $\begin{array}{c}\text { Peregangan } \\
\text { minimum } \\
(\%)\end{array}$ \\
\hline BJ 34 & 340 & 210 & 22 \\
\hline BJ 37 & 370 & 240 & 20 \\
\hline BJ 41 & 410 & 250 & 18 \\
\hline BJ 50 & 500 & 290 & 16 \\
\hline BJ 55 & 550 & 410 & 13 \\
\hline
\end{tabular}

(sumber: SNI 03-1729-2002)

Konstruksi kuda-kuda ialah suatu susunan rangka batang yang berfungsi untuk mendukung beban atap termasuk juga beratnya sendiri dan sekaligus dapat memberikan bentuk pada atapnya. Kuda-kuda merupakan penyangga utama pada struktur atap. Struktur ini termasuk dalam klasifikasi struktur framework (truss).

Rangka batang adalah susunan elemen-elemen linear yang membentuk segitiga atau kombinasi segitiga, sehingga membentuk rangka yang tidak dapat berubah bentuk apabila diberi beban eksternal.tanpa adanya perubahan bentuk pada satu atau lebih batangnya, setiap elemen tersebut secara khas dianggap tergabung pada titik hubung sendi. Batang-batang disusun sedemikian rupa sehingga semua beban dan reaksi hanya terjadi pada titik hubungan tersebut (Schodek 1991).

Pada dasarnya konstruksi kuda-kuda terdiri dari rangkaian batang atap yang senantiasa selalu membentuk segitiga, dengan mempertimbangkan berat atap serta bahan dan bentuk penutup atap, maka kuda-kuda satu sama lain akan berbeda. Namun demikian setiap susunan rangka batang haruslah merupakan suatu kesatuan bentuk yang kokoh yang nantinya mampu memikul beban yang diberikan padanya tanpa mengalami perubahan. pada penerapanya, kudakuda diletakan pada jarak tertentu sesuai dengan tempat yang telah direncanakan (Rahman 2009). 
Macam dan bentuk kuda-kuda pada umumnya adalah berbentuk segitiga, karena dengan bentuk ini mempunyai bidang yang miring, hal ini akan memperkecil tekanan angin dan mempercepat mengalirnya air yang jatuh dari atasnya.

Dibawah ini adalah gambar bentuk kuda-kuda :

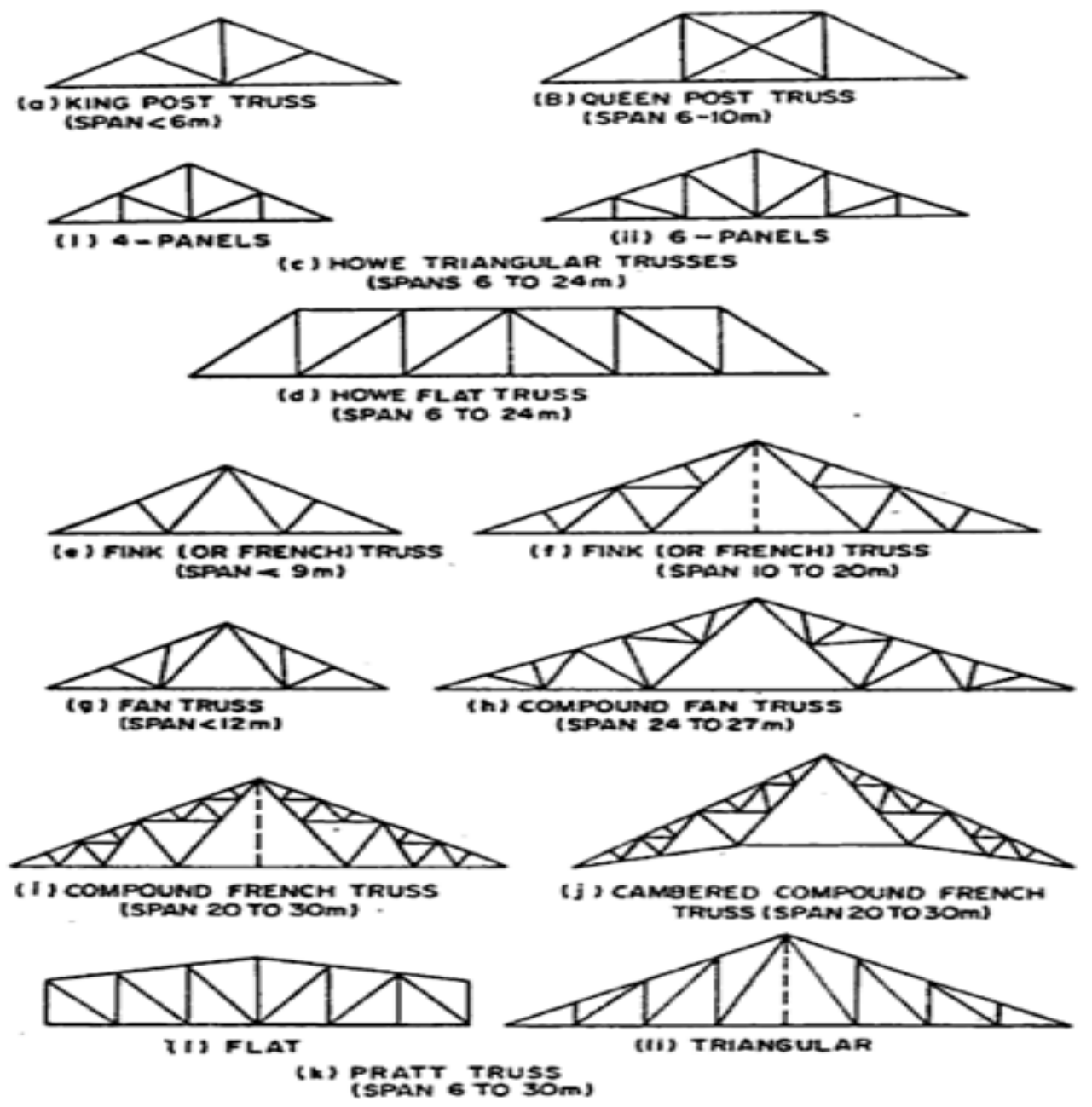

Gambar 1. Tipe kuda-kuda rangka atap baja.

(Punmia et all 1998)

Dari beberapa macam tipe desain kuda-kuda rangka atap baja pada gambar 1. akan diamati adalah bentuk desain Pratt Truss, Howe Truss, dan Compound Fan Truss.

1. Pratt Truss

Pratt Truss, awalnya dirancang oleh Thomas dan Caleb Pratt pada tahun 1844 (http://en.wikipedia.org 2011). Pratt Truss disusun sedemikian mungkin bahwa di bawah beban gravitasi elemen batang diagonal berfungsi untuk menahan gaya tarik dan elemen batang vertikal berfungsi untuk menahan gaya tekan. Hal ini memungkinkan untuk desain 
yang efisien. Akan tetapi akibat beban angin yang bekerja dapat menyebabkan pembalikan tegangan dan meniadakan manfaat ini (http://www.docstoc.com 2011).

2. Howe Truss

Howe Truss, pertama kali dipatenkan oleh Millwright Massachusetts William Howe pada tahun 1840 . Elemen batang Howe Truss merupakan kebalikan dari tipe Pratt Truss dimana elemen diagonal berfungsi untuk menahan gaya tekan sedangkan elemen batang vertikal berfungsi untuk menahan gaya tarik (http://en.wikipedia.org 2011).

3. Compound Fan Truss

Compound Fan Truss, merupakan gabungan dari kuda-kuda Fan Truss. berbeda dengan elemen batang Pratt Truss dan Howe Truss, elemen batang Compound Fan Truss berupa elemen diagonal yang berfungsi Untuk menahan gaya tarik dan tekan dimana elemen-elemen batang diagonal dari Compound Fan Truss saling mendukung dan memungkinkan untuk desain yang lebih efisien.

Penelitian terdahulu yaitu Perbandingan Volume Kebutuhan Material Baja Pada Struktur Rangka Kuda-Kuda Bentuk Pratt Girder dan Pratt Scissors oleh Rahman (2009) dengan membandingkan enam buah bentuk kuda-kuda yakni bentuk Pratt Girder dan Pratt Scisors dengan sudut $\theta$ adalah $2^{\circ}, 4^{\circ}, 6^{\circ}, 8^{\circ}$, dan $10^{\circ}$ pada bentang $15 \mathrm{~m}, 18 \mathrm{~m}$, dan $21 \mathrm{~m}$. Berdasarkan analisa perhitungan dan hasil penelitian diperoleh :

- Pada bentang $15 \mathrm{~m}$ kuda-kuda bentuk Pratt Scissors dengan $\theta=10^{\circ}$ memilki jumlah kebutuhan material baja terkecil dengan nilai $247,77 \mathrm{~kg}$ sedangkan kuda-kuda bentuk Pratt Girder memiliki jumlah kebutuhan terbesar dengan nilai $270,50 \mathrm{~kg}$.

- Pada bentang $18 \mathrm{~m}$ kuda-kuda bentuk Pratt Scissors dengan $\theta=6^{0}$ memiliki jumlah kebutuhan material baja terkecil yaitu $352,80 \mathrm{~kg}$ sedangkan kuda-kuda bentuk Pratt Girder memiliki jumlah kebuthan material baja terbesar pada bentang ini yaitu 409,92 kg

- Pada bentang $21 \mathrm{~m}$ kuda kuda bentuk Pratt Scissors dengan $\theta=10^{\circ}$ memilki jumlah kebutuhan baja paling sedikit yaitu 472,70 kg sedangkan kuda-kuda Pratt Girder memiliki jumlah kebutuhan yang paling terbesar pada bentang ini yaitu sebesar $600,41 \mathrm{~kg}$.

Perencanaan struktur kuda-kuda rangka atap baja dengan membandingkan bentuk kudakuda yang berbeda akan menghasilkan jumlah kebutuhan material baja yang berbeda pula 
sehingga akan didapatkan bentuk rangka kuda-kuda yang paling ekonomis ditinjau dari jumlah kebutuhan material baja yang diperlukan.

Kuda-kuda bentuk Pratt Truss (6-30 m), Howe Truss (6-24 m) dan Compound Fan Truss (24-27 m) dipilih dari banyaknya bentuk kuda-kuda yang ada ketiga bentuk kuda-kuda tersebut bisa dipergunakan pada kontruksi bangunan dengan bentangan yang besar seperti bangunan industri (pabrik), hanggar pesawat, gedung olahraga dan lain-lain.

\section{METODA}

Penelitian ini bertujuan untuk mengetahui perbandingan kebutuhan material baja pada kudakuda rangka atap tipe Pratt Truss, Howe Truss, dan Compound Fan Truss hanya pada bentangan 24 meter, sehingga dapat diketahui bentuk kuda-kuda yang paling ekonomis dalam penggunaan bahan material baja

Perhitungan analisa gaya-gaya batang yang berkerja pada kuda-kuda yang diteliti menggunakan program analisa struktur SAP 2000. Penggunaan program tersebut memiliki banyak kemudahan dan tingkat kevaliditasan yang baik. Analisa gaya-gaya batang dengan memasukan jenis-jenis beban dan kombinasi pembebanan yang bekerja pada kuda-kuda tersebut, akan menghasilkan gaya-gaya batang yang nantinya menentukan dimensi profil yang digunakan ketiga kuda-kuda tersebut. Setelah didapat dimensi profil yang digunakan pada kudakuda tipe Pratt Truss, Howe Truss, dan Compound Fan Truss selanjutnya dapat disimpulkan bentuk kuda-kuda yang paling efisien dalam penggunaan material baja dengan membandingkan volume kebutuhan material baja dari masing-masing bentuk kuda-kuda yang diteliti

\section{HASIL DAN PEMBAHASAN}

Bentuk Atap

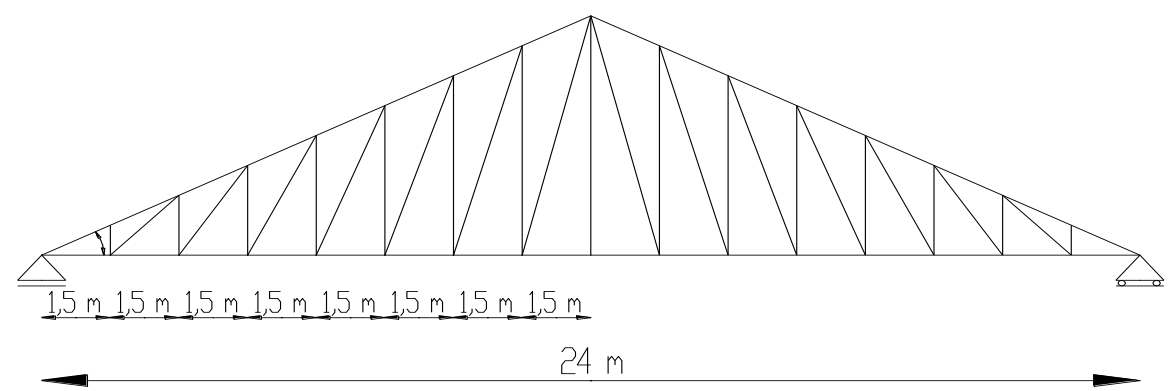

Gambar. 2. Kuda-kuda rangka atap baja tipe Pratt Truss 


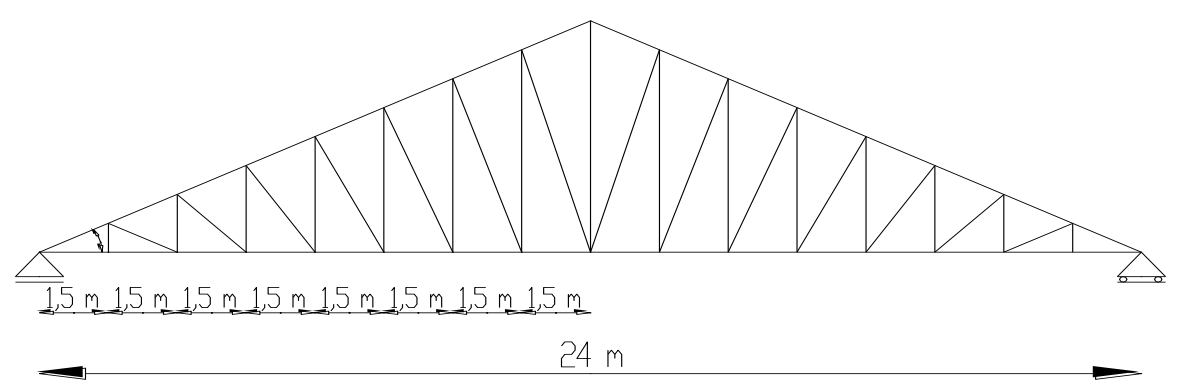

Gambar.3 Kuda-kuda rangka atap baja tipe Howe Truss

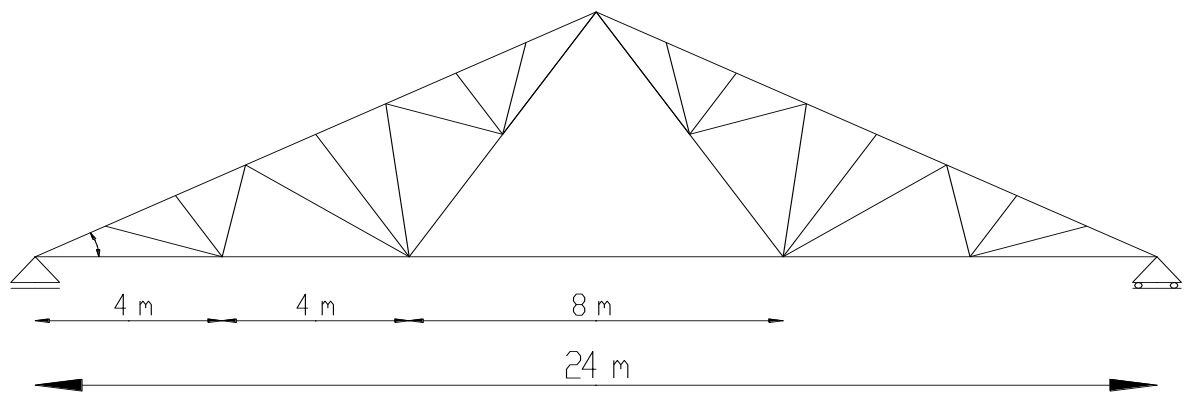

Gambar.4. Kuda-kuda rangka atap baja tipe Compound Fan Truss

Spesifikasi :

Bentang

Penutup atap

Sudut atap (a)

Jarak antar kuda-kuda

Jarak gording

Tegangan ijin baja

Jenis baja

Gording
: Bentang yang diperhitungkan adalah 24 meter.

: Genteng dengan berat sendiri sebesar $50 \mathrm{~kg} / \mathrm{m}^{2}$ (SNI 03-1727-1989).

$: 30 \circ$ karena menggunakan atap genteng

$: 3 \mathrm{~m}$

$: 1,73 \mathrm{~m}$

$: 2400 \mathrm{~kg} / \mathrm{cm}^{2}$

: BJ 37, fy $240 \mathrm{MPa}, f_{u} 370 \mathrm{Mpa}$

: Ukuran gording yang digunakan menggunakan profil kanal kait C.125.50.20.3,2.

Pembebanan yang diperhitungkan

a. Beban mati yang terdiri dari:
1) Berat sendiri atap
2) Berat sendiri gording
3) Berat sendiri kuda-kuda
4) Berat sendiri plafond + penggantung 
b. Beban hidup

Beban hidup pada atap harus diambil yang paling menentukan antara 2 macam beban berikut: (SNI 03-1727-1989).

1) Beban terbagi rata per $\mathrm{m}^{2}$ bidang datar berasal dari air hujan sebesar $(40-0,8 . a) \mathrm{kg} / \mathrm{m}^{2}$.

2) Beban terpusat dari seorang pekerja atau seorang pemadam kebakaran dengan peralatanya sebesar minimum $100 \mathrm{~kg}$.

C. Beban angin

Ditinjau dari kanan dan kiri yang tegak lurus bidang atap, besarnya beban angin adalah $25 \mathrm{~kg} / \mathrm{m}^{2}$.

d. Kombinasi Pembebanan

Kombinasi pembebanan yang diperhitungan sebagai input data pada program SAP 2000 mengunakan enam jenis kombinasi pembebanan sesuai dengan SNI 03-1729-2002 pasal 6.2.2. pada kombinasi keenam dibedakan menjadi dua kombinasi yaitu kombinasi 6 dan 7 (KOMBO 6 dan 7). Yang membedakan dua kombinasi tersebut adalah pada kombinasi 6 nilai faktor reduksi untuk beban angin (WIND) mengalami isapan (+), dan pada kombinasi 7 mengalami tekanan (-).

Perhitungan kebutuhan bahan material baja didapat setelah mengetahui nilai gaya batang dari hasil analisa program SAP 2000 yang bekerja pada elemen batang kuda-kuda rangka atap baja. Nilai gaya batang yang didapat digunakan untuk perhitungan struktur (sehingga didapat dimensi profil yang digunakan pada elemen batang kuda-kuda rangka atap baja yang sesuai dengan tabel baja untuk profil siku).

Pendimensian profil ketiga bentuk kuda-kuda rangka atap baja yang diteliti merupakan yang paling optimal dalam penggunaan bahan material baja. Perhitungan ketiga tipe kuda-kuda rangka atap baja didasarkan atas nilai gaya batang yang berkerja pada elemen batang-batang dari masing kuda-kuda tersebut. Nilai gaya batang yang berkerja pada ketiga kuda-kuda tersebut didapat dari hasil kombinasi pembebanan yang sesuai dengan peraturan SNI 03-1729-2002. Perhitungan nilai gaya batang yang berkerja pada ketiga tipe kuda-kuda rangka atap baja diperbantukan dengan penggunaan program SAP 2000 dengan memasukan enam jenis kombinasi pembebanan yang dilakukan sebelum melakukan analisa perhitungan untuk mencari gaya-gaya batang yang berkerja dengan menggunakan program SAP 2000. Dari hasil analisa yang menggunakan program SAP 2000 didapat salah satu kombinasi yang paling terbesar pada 
setiap batang dari kuda-kuda yang teliti. Perhitungan gaya-gaya batang masing-masing kudakuda rangka atap baja diambil yang paling terbesar nilai gaya batangnya. Dari hasil penelitian didapatkan bahwa nilai gaya batang yang terbesar didapat dari kombinasi 1 dan 3 (KOMBO 1 dan 3).

Tabel 2. Perhitungan Volume Material Baja Kuda-kuda Pratt Truss

\begin{tabular}{|c|c|c|c|c|c|c|c|}
\hline \multirow[t]{2}{*}{$\begin{array}{c}\text { No } \\
\text { Batang }\end{array}$} & \multirow[t]{2}{*}{ Nama Batang } & \multirow{2}{*}{$\begin{array}{c}\begin{array}{c}\text { Nilai } \\
\text { Gaya } \\
\text { Batang }\end{array} \\
\text { kg }\end{array}$} & \multirow[t]{2}{*}{$\begin{array}{l}\text { Jenis } \\
\text { Batang }\end{array}$} & $\begin{array}{l}\text { Panjang } \\
\text { Batang }\end{array}$ & \multirow[t]{2}{*}{$\begin{array}{c}\text { Jenis } \\
\text { Profil (2L) }\end{array}$} & \multirow{2}{*}{$\begin{array}{l}\text { Berat } \\
\text { Profil } \\
\mathrm{kg} / \mathrm{m}\end{array}$} & \multirow{2}{*}{$\begin{array}{r}\text { Berat } \\
\mathbf{k g}\end{array}$} \\
\hline & & & & $m$ & & & \\
\hline 1 & Batang Atas & $-12766,8$ & Tekan & 1,73 & 55.55 .6 & 9,9 & 17,13 \\
\hline 2 & Batang Atas & $-12778,8$ & Tekan & 1,73 & 55.55 .6 & 9,9 & 17,13 \\
\hline 3 & Batang Atas & $-12053,6$ & Tekan & 1,73 & 50.50 .6 & 8,94 & 15,47 \\
\hline 4 & Batang Atas & $-11291,6$ & Tekan & 1,73 & 50.50 .6 & 8,94 & 15,47 \\
\hline 5 & Batang Atas & $-10501,8$ & Tekan & 1,73 & 50.50 .6 & 8,94 & 15,47 \\
\hline 6 & Batang Atas & $-9685,52$ & Tekan & 1,73 & 50.50 .5 & 7,54 & 13,04 \\
\hline 7 & Batang Atas & $-8843,2$ & Tekan & 1,73 & 50.50 .5 & 7,54 & 13,04 \\
\hline 8 & Batang Atas & $-7974,69$ & Tekan & 1,73 & 50.50 .5 & 7,54 & 13,04 \\
\hline 9 & Batang Atas & $-7920,69$ & Tekan & 1,73 & 50.50 .5 & 7,54 & 13,04 \\
\hline 10 & Batang Atas & $-8753,2$ & Tekan & 1,73 & 50.50 .5 & 7,54 & 13,04 \\
\hline 11 & Batang Atas & $-9559,52$ & Tekan & 1,73 & 50.50 .5 & 7,54 & 13,04 \\
\hline 12 & Batang Atas & $-10339,8$ & Tekan & 1,73 & 50.50 .6 & 8,94 & 15,47 \\
\hline 13 & Batang Atas & $-11093,6$ & Tekan & 1,73 & 50.50 .6 & 8,94 & 15,47 \\
\hline 14 & Batang Atas & $-11819,61$ & Tekan & 1,73 & 50.50 .6 & 8,94 & 15,47 \\
\hline 15 & Batang Atas & $-12508,81$ & Tekan & 1,73 & 55.55 .6 & 9,9 & 17,13 \\
\hline 16 & Batang Atas & $-12532,81$ & Tekan & 1,73 & 55.55 .6 & 9,9 & 17,13 \\
\hline 17 & Batang Bawah & 11300,6 & Tarik & 1,5 & 40.40 .4 & 4,84 & 7,26 \\
\hline 18 & Batang Bawah & 10662,17 & Tarik & 1,5 & 40.40 .4 & 4,84 & 7,26 \\
\hline 19 & Batang Bawah & 9991,86 & Tarik & 1,5 & 40.40 .4 & 4,84 & 7,26 \\
\hline 20 & Batang Bawah & 9297,48 & Tarik & 1,5 & 40.40 .4 & 4,84 & 7,26 \\
\hline 21 & Batang Bawah & 8580,17 & Tarik & 1,5 & 40.40 .4 & 4,84 & 7,26 \\
\hline 22 & Batang Bawah & 7840,31 & Tarik & 1,5 & 40.40 .4 & 4,84 & 7,26 \\
\hline 23 & Batang Bawah & 7077,76 & Tarik & 1,5 & 40.40 .4 & 4,84 & 7,26 \\
\hline 24 & Batang Bawah & 6292,46 & Tarik & 1,5 & 40.40 .4 & 4,84 & 7,26 \\
\hline 25 & Batang Bawah & 6292,46 & Tarik & 1,5 & 40.40 .4 & 4,84 & 7,26 \\
\hline 26 & Batang Bawah & 7015,41 & Tarik & 1,5 & 40.40 .4 & 4,84 & 7,26 \\
\hline 27 & Batang Bawah & 7715,6 & Tarik & 1,5 & 40.40 .4 & 4,84 & 7,26 \\
\hline 28 & Batang Bawah & 8393,11 & Tarik & 1,5 & 40.40 .4 & 4,84 & 7,26 \\
\hline 29 & Batang Bawah & 9048,07 & Tarik & 1,5 & 40.40 .4 & 4,84 & 7,26 \\
\hline 30 & Batang Bawah & 9680,09 & Tarik & 1,5 & 40.40 .4 & 4,84 & 7,26 \\
\hline 31 & Batang Bawah & 10288,04 & Tarik & 1,5 & 40.40 .4 & 4,84 & 7,26 \\
\hline 32 & Batang Bawah & 10864,12 & Tarik & 1,5 & 40.40 .4 & 4,84 & 7,26 \\
\hline 33 & Batang vertikal & -568 & Tekan & 0,87 & 40.40 .4 & 4,84 & 4,21 \\
\hline 34 & Batang Diagonal & 975,22 & Tarik & 2,29 & 40.40 .4 & 4,84 & 11,08 \\
\hline 35 & Batang vertikal & $-973,8$ & Tekan & 1,73 & 40.40 .4 & 4,84 & 8,37 \\
\hline
\end{tabular}




\begin{tabular}{|c|c|c|c|c|c|c|c|}
\hline \multirow[t]{2}{*}{$\begin{array}{c}\text { No } \\
\text { Batang }\end{array}$} & \multirow[t]{2}{*}{ Nama Batang } & \multirow{2}{*}{$\begin{array}{c}\begin{array}{c}\text { Nilai } \\
\text { Gaya } \\
\text { Batang }\end{array} \\
\text { kg }\end{array}$} & \multirow[t]{2}{*}{$\begin{array}{l}\text { Jenis } \\
\text { Batang }\end{array}$} & $\begin{array}{l}\text { Panjang } \\
\text { Batang }\end{array}$ & \multirow[t]{2}{*}{$\begin{array}{c}\text { Jenis } \\
\text { Profil (2L) }\end{array}$} & $\begin{array}{l}\text { Berat } \\
\text { Profil }\end{array}$ & \multirow{2}{*}{$\begin{array}{r}\text { Berat } \\
\mathrm{kg}\end{array}$} \\
\hline & & & & $m$ & & $\mathrm{~kg} / \mathrm{m}$ & \\
\hline 36 & Batang Diagonal & 1340,61 & Tarik & 3 & 40.40 .4 & 4,84 & 14,52 \\
\hline 37 & Batang vertikal & $-1397,2$ & Tekan & 2,6 & 45.45 .5 & 6,76 & 17,58 \\
\hline 38 & Batang Diagonal & 1747,48 & Tarik & 3,77 & 45.45 .5 & 6,76 & 25,49 \\
\hline 39 & Batang vertikal & $-1845,1$ & Tekan & 3,46 & 60.60 .6 & 10,84 & 37,51 \\
\hline 40 & Batang Diagonal & 2191,42 & Tarik & 4,58 & 50.50 .5 & 7,54 & 34,53 \\
\hline 41 & Batang vertikal & $-2318,16$ & Tekan & 4,33 & 75.75 .7 & 15,88 & 68,76 \\
\hline 42 & Batang Diagonal & 2667,61 & Tarik & 5,4 & 60.60 .6 & 10,84 & 58,54 \\
\hline 43 & Batang vertikal & $-2816,6$ & Tekan & 5,19 & 90.90 .9 & 24,4 & 126,64 \\
\hline 44 & Batang Diagonal & 3174,74 & Tarik & 6,24 & 70.70 .7 & 14,76 & 92,1 \\
\hline 45 & Batang vertikal & $-3342,74$ & Tekan & 6,06 & 100.100 .10 & 30,2 & 183,01 \\
\hline 46 & Batang Diagonal & 3711,18 & Tarik & 7,08 & 80.80 .8 & 19,92 & 141,03 \\
\hline 47 & Batang vertikal & 247,8 & Tarik & 6,92 & 75.75 .7 & 15,88 & 109,89 \\
\hline 48 & Batang Diagonal & 3416,51 & Tarik & 7,08 & 80.80 .8 & 19,92 & 141,03 \\
\hline 49 & Batang vertikal & $-3054,74$ & Tekan & 6,06 & 100.100 .10 & 30,2 & 183,01 \\
\hline 50 & Batang Diagonal & 2915,14 & Tarik & 6,24 & 70.70 .7 & 14,76 & 92,1 \\
\hline 51 & Batang vertikal & $-2564,6$ & Tekan & 5,19 & 90.90 .9 & 24,4 & 126,64 \\
\hline 52 & Batang Diagonal & 2442,79 & Tarik & 5,4 & 60.60 .6 & 10,84 & 58,54 \\
\hline 53 & Batang vertikal & $-2102,16$ & Tekan & 4,33 & 75.75 .7 & 15,88 & 68,76 \\
\hline 54 & Batang Diagonal & 2000,93 & Tarik & 4,58 & 50.50 .5 & 7,54 & 34,53 \\
\hline 55 & Batang vertikal & $-1665,1$ & Tekan & 3,46 & 60.60 .6 & 10,84 & 37,51 \\
\hline 56 & Batang Diagonal & 1590,56 & Tarik & 3,77 & 45.45 .5 & 6,76 & 25,49 \\
\hline 57 & Batang vertikal & $-1253,2$ & Tekan & 2,6 & 45.45 .5 & 6,76 & 17,58 \\
\hline 58 & Batang Diagonal & 1215,9 & Tarik & 3 & 40.40 .4 & 4,84 & 14,52 \\
\hline 59 & Batang vertikal & $-865,8$ & Tekan & 1,73 & 40.40 .4 & 4,84 & 8,37 \\
\hline 60 & Batang Diagonal & 879,98 & Tarik & 2,29 & 40.40 .4 & 4,84 & 11,08 \\
\hline 61 & Batang vertikal & -496 & Tekan & 0,87 & 40.40 .4 & 4,84 & 4,21 \\
\hline \multicolumn{7}{|c|}{ TOTAL } & 2112,37 \\
\hline
\end{tabular}

Tabel 3. Perhitungan Volume Material Baja Kuda-kuda Howe Truss

\begin{tabular}{|c|l|c|c|c|c|c|c|}
\hline \multirow{2}{*}{$\begin{array}{c}\text { No } \\
\text { Batang }\end{array}$} & \multirow{2}{*}{ Nama Batang } & \multirow{2}{*}{$\begin{array}{c}\text { Nilai } \\
\text { Gaya } \\
\text { Batang }\end{array}$} & \multirow{2}{*}{$\begin{array}{c}\text { Jenis } \\
\text { Batang }\end{array}$} & $\begin{array}{c}\text { Panjang } \\
\text { Batang }\end{array}$ & $\begin{array}{c}\text { Jenis } \\
\text { Profil (2L) }\end{array}$ & $\begin{array}{c}\text { Berat } \\
\text { Profil }\end{array}$ & Berat \\
& & $\mathbf{k g}$ & & $\mathbf{m}$ & & $\mathbf{k g} / \mathbf{m}$ & $\mathbf{k g}$ \\
\hline 1 & Batang Atas & $-12555,6$ & Tekan & 1,73 & 55.55 .6 & 9,9 & 17,13 \\
\hline 2 & Batang Atas & $-11836,4$ & Tekan & 1,73 & 50.50 .6 & 9,9 & 17,13 \\
\hline 3 & Batang Atas & -11086 & Tekan & 1,73 & 50.50 .6 & 9,9 & 17,13 \\
\hline 4 & Batang Atas & $-10310,4$ & Tekan & 1,73 & 50.50 .5 & 7,54 & 13,04 \\
\hline 5 & Batang Atas & $-9509,84$ & Tekan & 1,73 & 50.50 .5 & 7,54 & 13,04 \\
\hline 6 & Batang Atas & -8684 & Tekan & 1,73 & 50.50 .5 & 7,54 & 13,04 \\
\hline 7 & Batang Atas & $-7832,74$ & Tekan & 1,73 & 50.50 .5 & 7,54 & 13,04 \\
\hline 8 & Batang Atas & $-6955,7$ & Tekan & 1,73 & 45.45 .5 & 6,76 & 11,69 \\
\hline 9 & Batang Atas & $-6973,7$ & Tekan & 1,73 & 45.45 .5 & 6,76 & 11,69 \\
\hline 10 & Batang Atas & $-7814,75$ & Tekan & 1,73 & 50.50 .5 & 7,54 & 13,04 \\
\hline 11 & Batang Atas & -8630 & Tekan & 1,73 & 50.50 .5 & 7,54 & 13,04 \\
\hline
\end{tabular}




\begin{tabular}{|c|c|c|c|c|c|c|c|}
\hline \multirow[t]{2}{*}{$\begin{array}{c}\text { No } \\
\text { Batang }\end{array}$} & \multirow[t]{2}{*}{ Nama Batang } & $\begin{array}{c}\text { Nilai } \\
\text { Gaya } \\
\text { Batang } \\
\end{array}$ & \multirow[t]{2}{*}{$\begin{array}{l}\text { Jenis } \\
\text { Batang }\end{array}$} & $\begin{array}{l}\text { Panjang } \\
\text { Batang }\end{array}$ & \multirow[t]{2}{*}{$\begin{array}{c}\text { Jenis } \\
\text { Profil (2L) }\end{array}$} & $\begin{array}{l}\text { Berat } \\
\text { Profil }\end{array}$ & \multirow{2}{*}{$\begin{array}{r}\text { Berat } \\
\mathrm{kg}\end{array}$} \\
\hline & & $\mathrm{kg}$ & & $\mathrm{m}$ & & $\mathrm{kg} / \mathrm{m}$ & \\
\hline 12 & Batang Atas & $-9419,84$ & Tekan & 1,73 & 50.50 .5 & 7,54 & 13,04 \\
\hline 13 & Batang Atas & $-10184,4$ & Tekan & 1,73 & 50.50 .5 & 7,54 & 13,04 \\
\hline 14 & Batang Atas & $-10924,01$ & Tekan & 1,73 & 50.50 .6 & 9,9 & 17,13 \\
\hline 15 & Batang Atas & $-11638,41$ & Tekan & 1,73 & 55.55 .6 & 9,9 & 17,13 \\
\hline 16 & Batang Atas & $-12321,61$ & Tekan & 1,73 & 55.55 .6 & 9,9 & 17,13 \\
\hline 17 & Batang Bawah & 11117,7 & Tarik & 1,5 & 40.40 .4 & 4,84 & 7,26 \\
\hline 18 & Batang Bawah & 11117,7 & Tarik & 1,5 & 40.40 .4 & 4,84 & 7,26 \\
\hline 19 & Batang Bawah & 10484,46 & Tarik & 1,5 & 40.40 .4 & 4,84 & 7,26 \\
\hline 20 & Batang Bawah & 9824,2 & Tarik & 1,5 & 40.40 .4 & 4,84 & 7,26 \\
\hline 21 & Batang Bawah & 9142,12 & Tarik & 1,5 & 40.40 .4 & 4,84 & 7,26 \\
\hline 22 & Batang Bawah & 8438,42 & Tarik & 1,5 & 40.40 .4 & 4,84 & 7,26 \\
\hline 23 & Batang Bawah & 7712,83 & Tarik & 1,5 & 40.40 .4 & 4,84 & 7,26 \\
\hline 24 & Batang Bawah & 6965,23 & Tarik & 1,5 & 40.40 .4 & 4,84 & 7,26 \\
\hline 25 & Batang Bawah & 6902,87 & Tarik & 1,5 & 40.40 .4 & 4,84 & 7,26 \\
\hline 26 & Batang Bawah & 7588,12 & Tarik & 1,5 & 40.40 .4 & 4,84 & 7,26 \\
\hline 27 & Batang Bawah & 8251,36 & Tarik & 1,5 & 40.40 .4 & 4,84 & 7,26 \\
\hline 28 & Batang Bawah & 8892,7 & Tarik & 1,5 & 40.40 .4 & 4,84 & 7,26 \\
\hline 29 & Batang Bawah & 9512,43 & Tarik & 1,5 & 40.40 .4 & 4,84 & 7,26 \\
\hline 30 & Batang Bawah & 10110,33 & Tarik & 1,5 & 40.40 .4 & 4,84 & 7,26 \\
\hline 31 & Batang Bawah & 10681,22 & Tarik & 1,5 & 40.40 .4 & 4,84 & 7,26 \\
\hline 32 & Batang Bawah & 10681,22 & Tarik & 1,5 & 40.40 .4 & 4,84 & 7,26 \\
\hline 33 & Batang vertikal & 166,6 & Tarik & 0,87 & 40.40 .4 & 4,84 & 4,21 \\
\hline 34 & Batang Diagonal & $-731,2$ & Tekan & 1,73 & 40.40 .4 & 4,84 & 8,37 \\
\hline 35 & Batang vertikal & 538,4 & Tarik & 1,73 & 40.40 .4 & 4,84 & 8,37 \\
\hline 36 & Batang Diagonal & $-1008,56$ & Tekan & 2,29 & 40.40 .4 & 4,84 & 11,08 \\
\hline 37 & Batang vertikal & 952 & Tarik & 2,6 & 40.40 .4 & 4,84 & 12,58 \\
\hline 38 & Batang Diagonal & $-1364,16$ & Tekan & 3 & 50.50 .5 & 7,54 & 22,62 \\
\hline 39 & Batang vertikal & 1389 & Tarik & 3,46 & 40.40 .4 & 4,84 & 16,75 \\
\hline 40 & Batang Diagonal & $-1770,93$ & Tekan & 3,77 & 65.65 .7 & 13,66 & 51,50 \\
\hline 41 & Batang vertikal & 1851,92 & Tarik & 4,33 & 50.50 .5 & 7,54 & 32,65 \\
\hline 42 & Batang Diagonal & $-2216,72$ & Tekan & 4,58 & 75.75 .7 & 15,88 & 72,73 \\
\hline 43 & Batang vertikal & 2340,6 & Tarik & 5,19 & 60.60 .6 & 10,84 & 56,26 \\
\hline 44 & Batang Diagonal & $-2695,52$ & Tekan & 5,4 & 90.90 .9 & 24,4 & 131,76 \\
\hline 45 & Batang vertikal & 2854,97 & Tarik & 6,06 & 70.70 .7 & 14,76 & 89,45 \\
\hline 46 & Batang Diagonal & $-3205,49$ & Tekan & 6,24 & 110.110 .10 & 30,2 & 188,45 \\
\hline 47 & Batang vertikal & 6328,9 & Tarik & 6,92 & 75.75 .7 & 15,88 & 109,89 \\
\hline 48 & Batang Diagonal & $-2965,75$ & Tekan & 6,24 & 110.110 .10 & 30,2 & 188,45 \\
\hline 49 & Batang vertikal & 2686,8 & Tarik & 6,06 & 70.70 .7 & 14,76 & 89,45 \\
\hline 50 & Batang Diagonal & $-2474,48$ & Tekan & 5,4 & 90.90 .9 & 24,4 & 131,76 \\
\hline 51 & Batang vertikal & 2194,03 & Tarik & 5,19 & 60.60 .6 & 10,84 & 56,26 \\
\hline 52 & Batang Diagonal & $-2026,22$ & Tekan & 4,58 & 75.75 .7 & 15,88 & 72,73 \\
\hline 53 & Batang vertikal & 1731,24 & Tarik & 4,33 & 50.50 .5 & 7,54 & 32,65 \\
\hline 54 & Batang Diagonal & $-1614,01$ & Tekan & 3,77 & 65.65 .7 & 13,66 & 51,50 \\
\hline 55 & Batang vertikal & 1298,5 & Tarik & 3,46 & 40.40 .4 & 4,84 & 16,75 \\
\hline
\end{tabular}




\begin{tabular}{|c|c|c|c|c|c|c|c|}
\hline \multirow{2}{*}{$\begin{array}{c}\text { No } \\
\text { Batang }\end{array}$} & \multirow[t]{2}{*}{ Nama Batang } & $\begin{array}{c}\text { Nilai } \\
\text { Gaya } \\
\text { Batana }\end{array}$ & \multirow{2}{*}{$\begin{array}{l}\text { Jenis } \\
\text { Batang }\end{array}$} & $\begin{array}{c}\text { Panjang } \\
\text { Batang }\end{array}$ & \multirow{2}{*}{$\begin{array}{c}\text { Jenis } \\
\text { Profil (2L) }\end{array}$} & $\begin{array}{l}\text { Berat } \\
\text { Profil }\end{array}$ & \multirow{2}{*}{$\begin{array}{c}\text { Berat } \\
\mathrm{kg}\end{array}$} \\
\hline & & $\mathrm{kg}$ & & $m$ & & $\mathrm{~kg} / \mathrm{m}$ & \\
\hline 56 & Batang Diagonal & $-1239,46$ & Tekan & 3 & 50.50 .5 & 7,54 & 22,62 \\
\hline 57 & Batang vertikal & 896 & Tarik & 2,6 & 40.40 .4 & 4,84 & 12,58 \\
\hline 58 & Batang Diagonal & $-913,31$ & Tekan & 2,29 & 40.40 .4 & 4,84 & 11,08 \\
\hline 59 & Batang vertikal & 520,8 & Tarik & 1,73 & 40.40 .4 & 4,84 & 8,37 \\
\hline 60 & Batang Diagonal & $-659,2$ & Tekan & 1,73 & 40.40 .4 & 4,84 & 8,37 \\
\hline 61 & Batang vertikal & 166,6 & Tarik & 0,87 & 40.40 .4 & 4,84 & 4,21 \\
\hline \multicolumn{7}{|c|}{ TOTAL } & $\begin{array}{c}1870,11 \\
72\end{array}$ \\
\hline
\end{tabular}

Tabel 4. Perhitungan Volume Material Baja Kuda-kuda Compound Fan Truss

\begin{tabular}{|c|c|c|c|c|c|c|c|}
\hline \multirow[t]{2}{*}{$\begin{array}{c}\text { No } \\
\text { Batang }\end{array}$} & \multirow[t]{2}{*}{ Nama Batang } & $\begin{array}{c}\text { Nilai } \\
\text { Gaya } \\
\text { Batang }\end{array}$ & \multirow[t]{2}{*}{$\begin{array}{l}\text { Jenis } \\
\text { Batang }\end{array}$} & $\begin{array}{l}\text { Panjang } \\
\text { Batang }\end{array}$ & \multirow[t]{2}{*}{$\begin{array}{l}\text { Jenis Profil } \\
\text { (2L) }\end{array}$} & $\begin{array}{l}\text { Berat } \\
\text { Profil }\end{array}$ & \multirow{2}{*}{$\frac{\text { Berat }}{\text { kg }}$} \\
\hline & & kg & & $\mathrm{m}$ & & $\mathrm{kg} / \mathrm{m}$ & \\
\hline 1 & Batang Atas & $-11266,72$ & Tekan & 1,73 & 50.50 .6 & 8,94 & 15,47 \\
\hline 2 & Batang Atas & $-10546,85$ & Tekan & 1,73 & 50.50 .6 & 8,94 & 15,47 \\
\hline 3 & Batang Atas & $-10269,68$ & Tekan & 1,73 & 50.50 .5 & 7,54 & 13,04 \\
\hline 4 & Batang Atas & $-8645,36$ & Tekan & 1,73 & 50.50 .5 & 7,54 & 13,04 \\
\hline 5 & Batang Atas & $-8357,11$ & Tekan & 1,73 & 50.50 .5 & 7,54 & 13,04 \\
\hline 6 & Batang Atas & $-9027,79$ & Tekan & 1,73 & 50.50 .5 & 7,54 & 13,04 \\
\hline 7 & Batang Atas & $-8750,64$ & Tekan & 1,73 & 50.50 .5 & 7,54 & 13,04 \\
\hline 8 & Batang Atas & $-8909,02$ & Tekan & 1,73 & 50.50 .5 & 7,54 & 13,04 \\
\hline 9 & Batang Atas & $-8675,01$ & Tekan & 1,73 & 50.50 .5 & 7,54 & 13,04 \\
\hline 10 & Batang Atas & $-8570,64$ & Tekan & 1,73 & 50.50 .5 & 7,54 & 13,04 \\
\hline 11 & Batang Atas & $-8847,79$ & Tekan & 1,73 & 50.50 .5 & 7,54 & 13,04 \\
\hline 12 & Batang Atas & $-8285,12$ & Tekan & 1,73 & 50.50 .5 & 7,54 & 13,04 \\
\hline 13 & Batang Atas & $-8573,36$ & Tekan & 1,73 & 50.50 .5 & 7,54 & 13,04 \\
\hline 14 & Batang Atas & $-10089,68$ & Tekan & 1,73 & 50.50 .5 & 7,54 & 13,04 \\
\hline 15 & Batang Atas & $-10366,85$ & Tekan & 1,73 & 50.50 .6 & 8,94 & 15,47 \\
\hline 16 & Batang Atas & $-11032,72$ & Tekan & 1,73 & 50.50 .6 & 8,94 & 15,47 \\
\hline 17 & Batang Bawah & 10001,49 & Tarik & 4 & 45.45 .5 & 6,76 & 27,04 \\
\hline 18 & Batang Bawah & 8909,05 & Tarik & 4 & 45.45 .5 & 6,76 & 27,04 \\
\hline 19 & Batang Bawah & 5416,36 & Tarik & 8 & 90.90 .9 & 24,4 & 195,20 \\
\hline 20 & Batang Bawah & 8597,28 & Tarik & 4 & 45.45 .5 & 6,76 & 27,04 \\
\hline 21 & Batang Bawah & 9565,01 & Tarik & 4 & 45.45 .5 & 6,76 & 27,04 \\
\hline 22 & Batang Diagonal & $-670,77$ & Tekan & 2,65 & 40.40 .4 & 4,84 & 12,83 \\
\hline 23 & Batang Diagonal & $-500,85$ & Tekan & 2 & 75.75 .7 & 15,88 & 31,76 \\
\hline 24 & Batang Diagonal & 1101,66 & Tarik & 2,65 & 40.40 .4 & 4,84 & 12,83 \\
\hline 25 & Batang Diagonal & $-1505,57$ & Tekan & 4,36 & 75.75 .7 & 15,88 & 69,24 \\
\hline 26 & Batang Diagonal & $-520,03$ & Tarik & 4 & 70.70 .7 & 14,76 & 59,04 \\
\hline 27 & Batang Diagonal & $-1217,05$ & Tekan & 4,36 & 75.75 .7 & 15,88 & 69,24 \\
\hline 28 & Batang Diagonal & 3768,33 & Tarik & 4 & 45.45 .5 & 6,76 & 27,04 \\
\hline 29 & Batang Diagonal & 751,43 & Tarik & 2,64 & 40.40 .4 & 4,84 & 12,78 \\
\hline 30 & Batang Diagonal & $-500,82$ & Tekan & 2 & 40.40 .4 & 4,84 & 9,68 \\
\hline
\end{tabular}




\begin{tabular}{|c|c|c|c|c|c|c|c|}
\hline \multirow{2}{*}{$\begin{array}{c}\text { No } \\
\text { Batang }\end{array}$} & \multirow{2}{*}{ Nama Batang } & $\begin{array}{c}\text { Nilai } \\
\text { Gaya } \\
\text { Batang }\end{array}$ & \multirow{2}{*}{$\begin{array}{c}\text { Jenis } \\
\text { Batang }\end{array}$} & $\begin{array}{c}\text { Panjang } \\
\text { Batang }\end{array}$ & \multirow{2}{*}{$\begin{array}{c}\text { Jenis Profil } \\
\mathbf{( 2 L}\end{array}$} & $\begin{array}{c}\text { Berat } \\
\text { Profil }\end{array}$ & Berat \\
& & $\mathbf{k g}$ & & $\mathbf{m}$ & & $\mathbf{k g} / \mathbf{m}$ & $\mathbf{k g}$ \\
\hline 31 & Batang Diagonal & $-670,76$ & Tekan & 2,65 & 45.45 .5 & 6,76 & 17,91 \\
\hline 32 & Batang Diagonal & 4941,11 & Tarik & 4 & 45.45 .5 & 6,76 & 27,04 \\
\hline 33 & Batang Diagonal & 4504,63 & Tarik & 4 & 45.45 .5 & 6,76 & 27,04 \\
\hline 34 & Batang Diagonal & $-588,27$ & Tekan & 2,65 & 45.45 .5 & 6,76 & 17,91 \\
\hline 35 & Batang Diagonal & $-438,46$ & Tekan & 2 & 40.40 .4 & 4,84 & 9,68 \\
\hline 36 & Batang Diagonal & 668,94 & Tarik & 2,64 & 40.40 .4 & 4,84 & 12,78 \\
\hline 37 & Batang Diagonal & 3466,86 & Tarik & 4 & 45.45 .5 & 6,76 & 27,04 \\
\hline 38 & Batang Diagonal & $-1081,15$ & Tekan & 4,36 & 75.75 .7 & 15,88 & 69,24 \\
\hline 39 & Batang Diagonal & $-457,68$ & Tekan & 4 & 70.70 .7 & 14,76 & 59,04 \\
\hline 40 & Batang Diagonal & $-1369,67$ & Tekan & 4,36 & 75.75 .7 & 15,88 & 69,24 \\
\hline 41 & Batang Diagonal & 1039,34 & Tarik & 2,65 & 40.40 .4 & 4,84 & 12,83 \\
\hline 42 & Batang Diagonal & $-438,5$ & Tekan & 2 & 75.75 .7 & 15,88 & 31,76 \\
\hline 43 & Batang Diagonal & $-588,28$ & Tekan & 2,65 & 40.40 .4 & 4,84 & 12,83 \\
\hline & & & & & & TOTAL & 1220,51 \\
\hline
\end{tabular}

Nilai kebutuhan untuk setiap kuda-kuda disajikan dalam bentuk diagram.

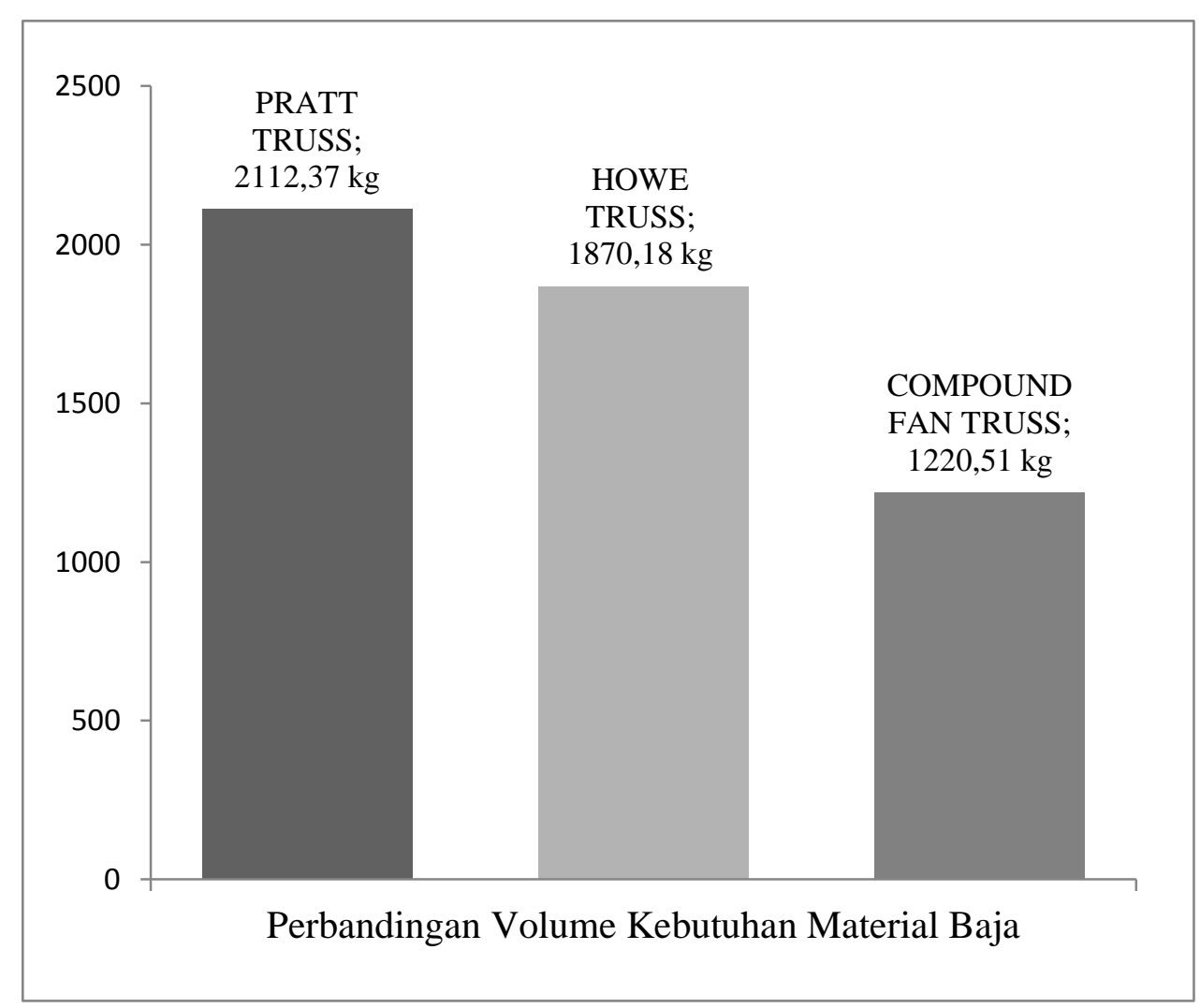

Gambar.5 Diagram perbandingan kebutuhan material baja

Dari hasil yang didapat, kuda-kuda Pratt Truss adalah jenis kuda-kuda rangka atap baja yang terbesar dalam penggunaan bahan material baja pada bentangan $24 \mathrm{~m}$ dengan nilai 
sebesar 2112,37 kg. Hasil ini didapatkan dari jumlah keseluruhan berat volume seluruh dimensi profil yang dipergunakan pada kuda-kuda rangka atap baja tersebut. Nilai gaya batang yang berkerja pada batang-batang tersebut digunakan untuk mengetahui besarnya dimensi profil yang dapat digunakan dengan memperhatikan syarat kekuatan suatu penampang untuk menahan besarnya gaya batang yang diterima oleh penampang tersebut. Syarat lain yang harus diperhatikan dalam menentukan dimensi profil yang digunakan pada penampang tersebut adalah syarat kelangsingan suatu penampang yang besarnya ditentukan berdasarkan panjang suatu penampang tersebut yang kemudian ditentukan nilai batasannya oleh peraturan yang berlaku yaitu SNI 03-1729-2002.

Kuda-kuda rangka atap baja tipe Howe Truss merupakan kuda-kuda rangka atap baja yang lebih sedikit penggunaan material bahan bajanya dibandingkan kuda-kuda Pratt Truss dengan nilai 1870,18 $\mathrm{kg}$ dan nilai prosentasenya sebesar 88,5 \% dari jumlah pemakaian kudakuda rangka atap baja tipe Pratt Truss. Pada batang atas penggunaan material baja kuda-kuda ini lebih ringan 9,1 kg dari kuda-kuda Pratt Truss. Pada batang bawah tidak terdapat perbedaaan dengan kuda-kuda Pratt Truss. Namun, pada batang vertikal terdapat perbedaan yang sangat besar pada kuda-kuda ini dibandingkan kuda-kuda Pratt Truss walaupun panjang elemenelemen batang tersebut sama besarnya dengan selisih nilai lebih ringan 451,62 kg. Hal ini dikarenakan pada batang vertikal kuda-kuda ini berkerja gaya tarik sedangkan pada kuda-kuda Pratt Truss bekerja gaya tekan sehingga pada batang-batang vertikal kuda-kuda tersebut lebih ringan dari kuda-kuda Pratt Truss karena sifat baja yang lebih kuat dalam menahan gaya tarik. Pada batang diagonal kuda-kuda ini lebih besar pemakaian material bajanya daripada kuda kuda Pratt Truss dengan selisih nilai 218,44 kg lebih berat dari kuda-kuda rangka atap baja tipe Pratt Truss. Hal ini dikarenakan jenis batang tersebut merupakan batang tekan sehingga akibat dari faktor kelangsingan suatu penampang, penggunaan material bajanya lebih besar dari Tipe Pratt Truss walaupun panjang batang diagonal pada tipe kuda-kuda ini lebih kecil dari kuda-kuda Pratt Truss.

Kuda-kuda rangka atap baja tipe Compound Fan Truss merupakan kuda-kuda yang terkecil pemakaian material bajanya daripada jenis kuda-kuda rangka atap baja yang lainnya dengan nilai sebesar 1220,51 dengan prosentase sebesar $57,8 \%$ dari pemakaian material kudakuda rangka atap baja tipe Pratt Truss. Hal ini dapat dilihat dari jumlah kebutuhan pemakaian material baja pada batang atas dengan selisih nilai lebih ringan $21,22 \mathrm{~kg}$ dari kuda-kuda rangka atap baja tipe Pratt Truss. Namun pada batang bawah kuda-kuda ini lebih besar dari kuda-kuda yang lainnya dikarenakan pada batang-batang bawah kuda-kuda ini memiliki panjang batang 
yang lebih panjang sehingga karena faktor kelangsingan suatu penampang, maka dimensi profil yang didapat lebih berat dan lebih boros pemakaian material bajanya. pada batang pengisi kudakuda ini tidak terdapat batang vertikal, hanya batang diagonal saja yang saling menyokong elemen batang yang lainnya. Panjang elemen batang pengisi berkisar antara 2 - 4,36 m dan jumlah keseluruhan elemen batang Compound Fan Truss lebih sedikit dari kuda-kuda yang lainnya sehingga elemen batang pengisi kuda-kuda ini bila dijumlahkan akan lebih ringan dari kuda-kuda yang lainnya.

\section{KESIMPULAN}

Berdasarkan hasil penelitian, Tipe kuda-kuda Compound Fan Truss memiliki jumlah kebutuhan material baja yang terkecil pada bentangan 24 m dengan nilai 1220,51 kg, kuda-kuda Bentuk Howe truss memiliki jumlah kebutuhan material baja lebih besar dari kuda-kuda Compound Fan Truss dengan nilai 1870,12 kg, sedangkan kuda-kuda bentuk Pratt Truss memiliki jumlah kebutuhan material paling besar pada bentang ini dengan jumlah kebutuhan material baja mencapai nilai $2112,37 \mathrm{~kg}$.

\section{DAFTAR PUSTAKA}

Dep. Pemukiman dan Prasarana Wilayah. 2002, Tata Cara Perencanaan Struktur Baja Untuk Bangunan Gedung (SNI 03-1729-2002), Jakarta.

Dep. Pemukiman dan Prasarana Wilayah, 2002,. Metode, Spesifikasi dan Tata Cara (SNI-031727-1989 Tata Cara Perencanaan Pembebanan Untuk Rumah dan Gedung). Jakarta:

ILT Learning., 2008, Belajar Sendiri SAP 2000 Versi 10. PT. Gramedia, Jakarta

Lambri, Bustraan Z., 2001, Daftar-Daftar Untuk Konstruksi Baja.: Pradnya Paramitha, Jakarta

Punmia, B. C. Jain, Ashok Kumar. Jain, Arun Kumar. , 1998, Comprehensive Design of Steel Structures. Fire Wall

Rahman, Zulika. 2009, Perbandingan Volume Kebutuhan Material Baja pada Struktur Rangka Kuda-Kuda Bentuk Pratt Girder dan Pratt Scissors. Jakarta: Universitas Negeri Jakarta,

Raguhpati, M. 1995, Design of Steel Structure.: Tata Mcgrow-Hill Publishing Company Limited, New York

Setiawan, Agus. 2008, Perencanaan Struktur Baja Dengan Metoda LFRD., Erlangga Jakarta

Schodek, Daniel L. Struktur. Bambang suryoatmono, penerjemah. Bandung: Eresco, 1991.

http://books.google.co.id/books?id=pXekq3FNMUYC\&pg=PA520\&dq=design+steel+of+structure.

[Kamis, 21 April 2011, 23.00] 
http://en.wikipedia.org/wiki/Truss [Kamis, 21 April 2011, 23.30].

http://www.docstoc.com/docs/4530709/Design-of-Steel-Structures-Prof-S-R-Satish-Kumar. [Rabu, 08 Juni 2011, 15.16]

http://repository.usu.ac.id/bitstream/123456789/21686/3/Chapter\%20ll.pdf [kamis, 21 april 2011 24.00] 